\title{
Azospirillum Inoculation Alters Nitrate Reductase Activity and Nitrogen Uptake in Wheat Plant under Water Deficit Conditions
}

\author{
N. Aliasgharzad ${ }^{\# 1}$, Z. Heydaryan ${ }^{\# 2}$, M.R. Sarikhani ${ }^{\# 3}$ \\ \# Department of Soil Science, University of Tabriz, Tabriz, 51664-16471, Iran \\ E-mail: ${ }^{1}$-aliasghar@tabrizu.ac.ir, ${ }^{2}$ zahra_heydaryan@yahoo.com, ${ }^{3}$ rsarikhani@yahoo.com
}

\begin{abstract}
Water deficit stress usually diminishes nitrogen uptake by plants. There are evidences that some nitrogen fixing bacteria can alleviate this stress by supplying nitrogen and improving its metabolism in plants. Four Azospirillum strains, A. lipoferum AC45II, A. brasilense AC46-I, A. irakense AC49-VII and A. irakense AC51-VI were tested for nitrate reductase activity (NRA). In a pot culture experiment using a sandy loam soil, wheat plants (Triticum aestivum L. cv. Sardari) were inoculated with these bacterial strains and three ranges of soil water potential (W1: -10 to -20 , W2: -40 to -50 and $W 3:-65$ to $-75 \mathrm{kPa}$ ) were applied to the pots. All strains were positive in NRA test and the highest $\left(7.63 \mathrm{mg} \mathrm{NO}-\mathrm{N}_{2} \cdot \mathrm{L}^{-1} .48 \mathrm{~h}^{-1}\right)$ was recorded for $\mathrm{AC49}-\mathrm{VII}$ and the least $\left(0.23 \mathrm{mg} \mathrm{NO}_{2}-\right.$ N.L $\mathrm{L}^{-1} . \mathbf{4 8 \mathrm { h } ^ { - 1 }}$ ) was belong to AC51-VI. Leaf and root NRA, root and shoot nitrogen concentrations, and dry weights of root and shoot decreased by increasing water deficit stress. All four bacterial strains caused a significant enhancement in root NRA and in each water deficit level, the higher root NRA was recorded in AC46-I and AC49-VII inoculated plants. The highest leaf NRA was achieved by AC49-VII. The mean increment of root NRA by bacterial strains was $171 \%$ compared to the non-bacterial plants. Moreover, at the highest level of water deficit stress, the highest dry weight and nitrogen concentration in root and shoot were obtained by AC46-I and AC49-VII treatments.
\end{abstract}

Keywords - Azospirillum, Nitrate reductase, water deficit, nitrogen fixation, Wheat.

\section{INTRODUCTION}

Water is expected to be one of the most critical natural resources in the twenty-first century. Twenty-six countries are now classified as water deficient, and nearly 230 million people are affected with water shortage and the prediction is that by 2025 , one quarter of the world's population will face severe water shortage [1].

Nitrogen is one of the most important mineral nutrients for plants and is taken up by the root system predominantly in inorganic forms $\left(\mathrm{NH}_{4}{ }^{+}\right.$and $\left.\mathrm{NO}_{3}{ }^{-}\right)$. Nitrogen is mainly absorbed as nitrate, which is the most common nitrogen source available for higher plants. Nitrate assimilation is the primary pathway by which reduced nitrogen is accumulated in plants; that involves a consecutive action of two enzymes: nitrate reductase, a cytosolic enzyme that reduces nitrate to nitrite using NADPH as electron donor, and nitrite reductase, a plastidic enzyme that reduces nitrite to ammonium [2].

It is generally accepted that water deficit has a negative effect on $\mathrm{N}$ concentrations, free amino acids or soluble protein contents accompanied with a decline of nitrate reductase activity (NRA) in many plant species, such as wheat [3], potato [4], maize [5] or other plants [6]. The nitrate reductase activity decline during water stress is mainly attributed to low $\mathrm{NO}_{3}{ }^{-}$absorption and availability resulting from water uptake deprivation [7]. In a field experiment two barley varieties and one durum wheat variety were subjected to irrigation at different rates in relatively dry Mediterranean environment with different nitrogen fertility. Although decreasing irrigation water in soil caused a drop of plant leaf water potential from -1.5 to 3.0 $\mathrm{MPa}$, nitrate reductase activity of the leaves in these plants in the stage of heading was unaffected or slightly increased; on the other hand, it was the highest in the plants growing with an ample nitrogen supply irrespective of water regime [8]. In maize plants, desiccation leads to a steady decrease of NRA with a concomitant decrease in leaf water potential, leaf $\mathrm{NO}_{3}^{-}$flux [9]. When rewatered, water-stressed maize plants recovered partially and showed an increase in NRA and $\mathrm{NO}_{3}^{-}$flux [10]. To overcome, at least partially, the effect of water deficit stress, some measures have been suggested. By increasing soil fertility, especially with nitrogenous fertilizers the adverse effect of water stress can be alleviated substantially [11].

Azospirillum has been reported to improve nitrogen supply in association with cereals, although the mode of interaction between plants and bacteria is not fully understood [12], [13]. It is not clear whether bacteria provide an excess of fixed nitrogen that is supplied to the plant. An 
alternative to $\mathrm{N}_{2}$ fixation as an explanation for $\mathrm{N}$ accumulation following Azospirillum inoculation is bacterial nitrate reductase theory. Field experiments with Azospirillum inoculants demonstrated an increase of uptake and assimilation of soil nitrogen and other plant nutrients [14], [15], [16]. This was confirmed with a nitrate reductase negative mutant of strain Sp245, which had no effect. Wheat inoculated with two A. brasilense strains Sp245 and Sp107 repeatedly showed increased plant growth and $\mathrm{N}$-uptake [17]. Considering these results, it is not clear that the increased nitrogen assimilation in water-stressed plant is an action of bacterial NRA, induced NRA of plant or both.

The aim of this work was to investigate the effect of four Azospirillum strains on nitrogen nutrition, root and shoot dry weights, leaf chlorophyll content, and root and shoot nitrate reductase activities of wheat plant under water deficit stress conditions.

\section{MATERIALS AND METHODS}

\section{A. Bacterial strains}

Four Azospirillum strains including A. lipoferum AC45-II, A. brasilense AC46-I, A. irakense AC49-VII and A. irakense AC51-VI supplied by Soil Science Department, Gorgan University of Agricultural Sciences and Natural Resources, and were tested for nitrate reductase activity as described by Dubey and Maheshwari [18]. Auxin production and nitrogenase activity of these strains were reported by Ghaderi Golezani [19]. These bacterial characteristics are shown in Table1. Bacterial strains were propagated in liquid malate medium supplied with 0.2 g. $\mathrm{L}^{-1}$ yeast extract for $24 \mathrm{~h}$ at $28{ }^{\circ} \mathrm{C}$ on a shaker-incubator at $120 \mathrm{rpm}$ [20]. Bacterial cell density was adjusted on $10^{8} \mathrm{CFU} / \mathrm{ml}$ using OD determination at $540 \mathrm{~nm}$. Bacterial suspensions were mixed with micronized $(<10 \mu \mathrm{m})$ and sterile expanded-vermiculite and then used as inoculums.

\section{B. Plant material and bacterial inoculation}

Seeds of wheat (Triticum aestivum L. cv. Sardari) were surface sterilized by immersion in ethanol $96 \%$ for $5 \mathrm{sec}$, followed by immersion in sodium hypochlorite $0.5 \%$ for 5 min and rinsed with sterile distilled water for 10 times. Seeds were kept on wet sterile filter papers in Petri dishes for $24 \mathrm{~h}$ at $18{ }^{\circ} \mathrm{C}$ in dark, then transferred to refrigerator (4 ${ }^{\circ} \mathrm{C}$ ) and kept for further 17 days for vernalization. Six germinated seeds were transplanted into each pot containing $2.4 \mathrm{~kg}$ sterile sandy loam soil. The main characteristics of the soil were: $\mathrm{pH} 7.6$, ECe $1.6 \mathrm{dSm}^{-1}, 0.49 \%$ organic carbon, $17 \%$ clay, $22.3 \%$ silt, $60.7 \%$ sand, $6.66 \mathrm{mgkg}^{-1}$ Olsen P, $224.1 \mathrm{mgkg}^{-1}$ available $\mathrm{K}$ and $11.2 \% \mathrm{CaCO}_{3}$.

Bacterial inoculums were used at a rate of $10^{7} \mathrm{CFU} / \mathrm{g}$ per seed. Non-bacterial controls received sterile vermiculite mixed with bacteria-free malate medium. Based on soil test, all pots equally received $\mathrm{K}$ (as $\mathrm{K}_{2} \mathrm{SO}_{4}$ ) and $\mathrm{P}$ (as triple superphosphate).

\section{Water deficit treatments}

At the beginning of the second week after sowing, plants were thinned down to three per pot and soil moisture content was adjusted to three ranges of soil water potential including, -10 to $-20 \mathrm{kPa}$ (no water deficit), -40 to $-50 \mathrm{kPa}$ (medium water deficit) and -65 to $-75 \mathrm{kPa}$ (high water deficit). Soil moisture content (w/w) at each range was determined using pressure plate method, and pots watered by weighing each day. Pots were arranged in a factorial randomized complete block design with four replications. Plants were kept in a greenhouse under a $16 \mathrm{~h}$ photoperiod, $25 / 20 \pm 3^{\circ} \mathrm{C}$ (day/night, temperatures) and $40-60 \%$ relative humidity.

\section{Chlorophyll index, plant nitrogen and dry weight}

After $80 \mathrm{~d}$ of sowing, chlorophyll index was measured using chlorophyll meter (Hansatech CL-01). Shoots and roots were dried in an oven at $60{ }^{\circ} \mathrm{C}$ to constant mass, then weighed and ground for further analysis. Root and shoot nitrogen concentrations were measured using Kjeldahl method.

\section{E. Nitrate reductase assay in leaf and root}

Nitrate reductase activity was determined by the method of Jaworski [21] as follows: one-gram sample of fresh plant tissue was incubated for $30 \mathrm{~min}$ at $30{ }^{\circ} \mathrm{C}$ in assay medium ( $\mathrm{pH} 7$ ), then boiled at $100{ }^{\circ} \mathrm{C}$ for $5 \mathrm{~min}$. The nitrite was then determined colorimetrically using sulphanilic acid and $\alpha$ naphthylamine solution at $520 \mathrm{~nm}$.

\section{RESULTS AND DISCUSSION}

\section{A. Bacterial NRA}

As shown in Table 1, all four bacterial strains were positive in NRA test and the highest $\left(7.63 \mathrm{mg} \mathrm{NO}_{2}-\mathrm{N} . \mathrm{L}^{-}\right.$ $\left.{ }^{1} .48 \mathrm{~h}^{-1}\right)$ and least $\left(0.23 \mathrm{mg} \mathrm{NO} \mathrm{N}_{2}-\mathrm{N} . \mathrm{L}^{-1} .48 \mathrm{~h}^{-1}\right)$ were recorded for AC49-VII and AC51-VI, respectively. The maximum and minimum nitrogenase activities were seen in AC49-VII and AC45-II, respectively. Accordingly, the highest and least auxin productions were achieved by AC46-I and AC45II, respectively. As it appears, the strains are markedly different in these criteria and one strain is not efficient in all cases.

TABLE I

SOME CHARACTERISTICS OF BACTERIAL STRAINS

\begin{tabular}{|l|l|l|l|}
\hline \multirow{2}{*}{$\begin{array}{l}\text { Bacterial } \\
\text { strains }\end{array}$} & \multicolumn{3}{|c|}{ Some characteristics of bacterial strains } \\
\cline { 2 - 4 } & $\begin{array}{l}\text { Nitrogenase } \\
\left(\mathbf{n m o l ~} \mathbf{C}_{2} \mathbf{H}_{\mathbf{4}} \mathbf{~}^{-\mathbf{1}} \mathbf{~ m l}^{-\mathbf{1}}\right)\end{array}$ & $\begin{array}{l}\mathbf{N O}_{\mathbf{3}}^{-} \text {reductase } \\
\left(\mathbf{m g ~ N O}_{\mathbf{2}}-\mathbf{N ~ L}^{-1}\right. \\
\left.\mathbf{4 8 h}^{-1}\right)\end{array}$ & $\begin{array}{l}\text { Auxin production } \\
\left(\mathbf{m g ~ L}^{-\mathbf{1}} \mathbf{1 2 0 h}^{-1}\right)\end{array}$ \\
\hline AC45-II & $25.81 \mathrm{~d}$ & $5.82 \mathrm{~b}$ & $01.67 \mathrm{~d}$ \\
\hline AC46-I & $38.56 \mathrm{c}$ & $3.23 \mathrm{c}$ & $17.33 \mathrm{a}$ \\
\hline AC49-VII & $60.64 \mathrm{a}$ & $7.63 \mathrm{a}$ & $09.25 \mathrm{c}$ \\
\hline AC51-VI & $56.71 \mathrm{~b}$ & $0.23 \mathrm{~d}$ & $15.73 \mathrm{~b}$ \\
\hline
\end{tabular}

Means in each column followed by same letter are not significantly different at $\mathrm{P}<0.05$

\section{B. Chlorophyll index}

Regardless of bacterial strains, chlorophyll index was significantly decreased by increasing water deficit stress. However, in each water deficit level, the chlorophyll index of bacterial treated plants was higher than non-bacterial controls. The strain AC49-VII with higher nitrogen fixing capacity and nitrate reductase activity, was the efficient bacterium in enhancing chlorophyll index (Fig.1). Nitrogen is an essential nutrient in chlorophyll synthesis, and soil 
water depletion causes a marked decline in nitrogen transport in soil and its uptake by plant [22]. Higher nitrogen fixation and nitrate reductase activity of AC49-VII may compensate these problems and promote chlorophyll synthesis in each soil moisture level.

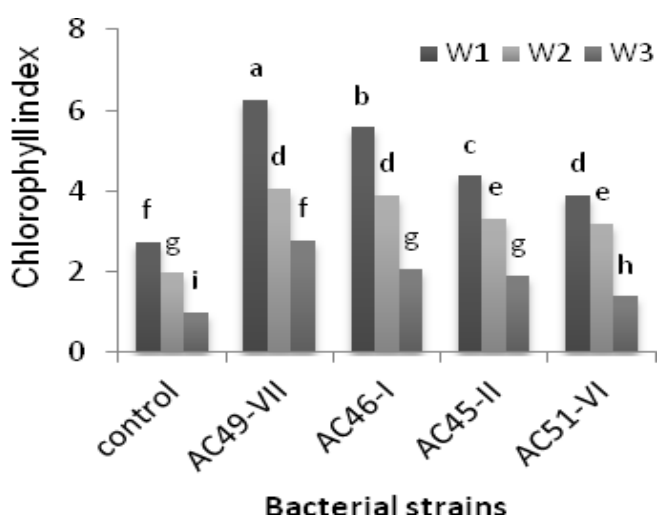

Fig. 1 Effects of soil water deficit levels and bacterial strains on chlorophyll index of leaf.

\section{Shoot and root dry weights}

Inoculation with bacterial strains led to an increase $(\mathrm{P}<0.05)$ in shoot and root dry weights compared to the nonbacterial control. Although root and shoot dry matters decreased by increasing water deficit, but in each soil water level, bacterial inoculated plants had significantly higher dry weight than non-bacterial treatments. At all soil moisture levels, the highest shoot and root dry matters were recorded in AC46-I and AC49-VII treated plants (Fig. 2 and Fig. 3). These bacterial strains exert their beneficial effects through nitrogen fixation, nitrate assimilation, auxin production and likely other plants growth promoting effects. There appears to be a positive relation between bacterial NRA and plant growth promotion perhaps by supplying easily metabolizable nitrogen to the plant roots. Abdel-Samad et al. [23] pointed out that the water deficit in soil is the most limiting factor in nitrogen flux toward the root and $\mathrm{N}_{2}$ fixation by Azospirillum in vicinity of roots can overcome this problem.

\section{Shoot and root $N$ concentrations}

Except for AC45-II with lower nitrogenase activity and auxin production, three other bacterial strains significantly enhanced $\mathrm{N}$ concentration in shoot and root compared to the non-bacterial controls. The highest shoot $\mathrm{N}$ was recorded in AC49-VII treated plants while both AC46-I and AC49-VII were the efficient strains in enhancing root N. Regardless of bacterial strains, decreasing soil water potential caused a marked decrease in shoot and root $\mathrm{N}$, although at each soil matric potential level, shoot and root $\mathrm{N}$ were higher $(\mathrm{P}<0.05)$ in bacterial than non-bacterial plants. The rate of decrease in plant tissue $\mathrm{N}$ by soil water depletion was stepper in shoot than root part (Fig. 4 and Fig. 5). Strain AC51-VI with relatively higher nitrogenase but very low NR activities (Table 1), could only slightly increased shoot and root N. It seems that the NRA of bacteria is also necessary in N incorporation into plant. Dannerberg et al. [24] stated that wheat plants inoculated with Azospirillum-NR+ had more N content than Azospirillum-NR- treated plants.

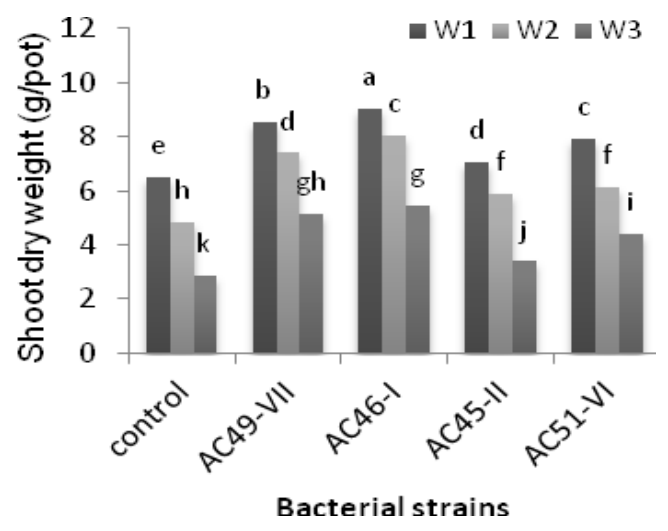

Fig. 2 Effects of soil water deficit levels and bacterial strains on shoot dry weight.

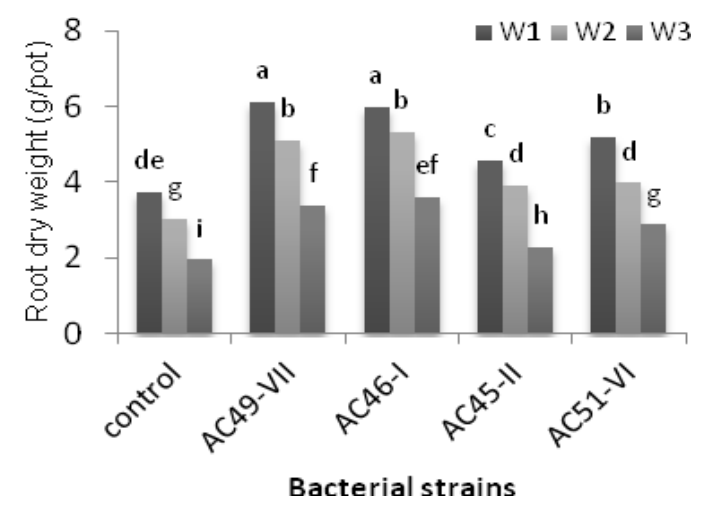

Fig. 3 Effects of soil water deficit levels and bacterial strains on root dry weight.

\section{E. Leaf and root NRA}

Leaf nitrate reductase activity diminished by increasing soil water deficit. At W1 and W2 levels, all bacterial strains caused a significant increase in leaf NRA compared to the non-bacterial controls, but at higher water deficit (W3) only AC49-VII was the efficient strain (Fig. 6). Relatively same trend was found in root NRA, but the strains were also efficient at W3 level and showed a significant increment in root NRA in all soil water levels compared to the nonbacterial controls (Fig. 7). Relatively higher NRA in root than leaf is due to higher supplying of $\mathrm{NO}_{3}{ }^{-}$(as substrate for nitrate reductase) to the root. Warembourg et al. [25] indicated that in associative and free living $\mathrm{N}_{2}$ fixers, the nitrogen products (ammonium or amino acids) are usually converted to the $\mathrm{NO}_{3}{ }^{-}$by soil microorganisms and this ion is preferable nitrogen source for nearly all plants. EL-Komy et al. [26] pointed out that the higher NRA in root can reduces $\mathrm{NO}_{3}{ }^{-}$to lower oxidation states and then these reduced forms of nitrogen are transferred to the leaf. Hence, nitrate concentration and nitrate reductase activity diminish in green part of plant. 


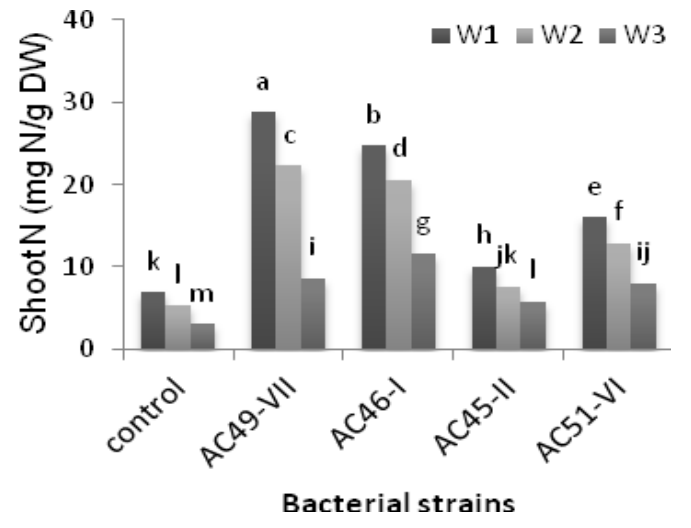

Fig. 4 Effects of soil water deficit levels and bacterial strains on shoot $\mathrm{N}$ concentration.

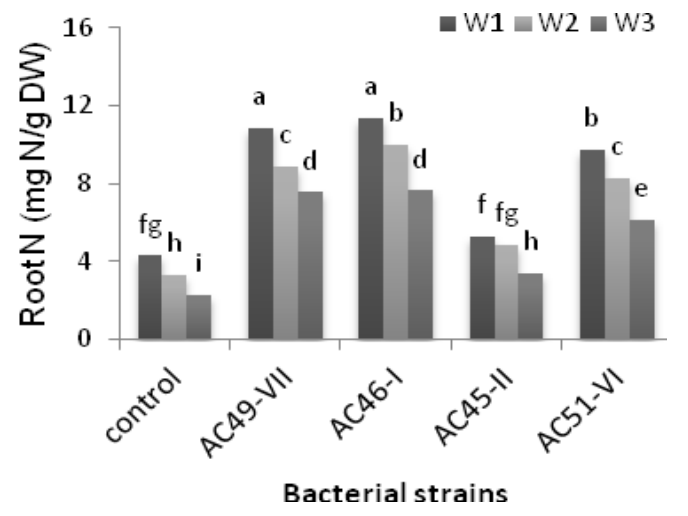

Fig. 5 Effects of soil water deficit levels and bacterial strains on root $\mathrm{N}$ concentration.

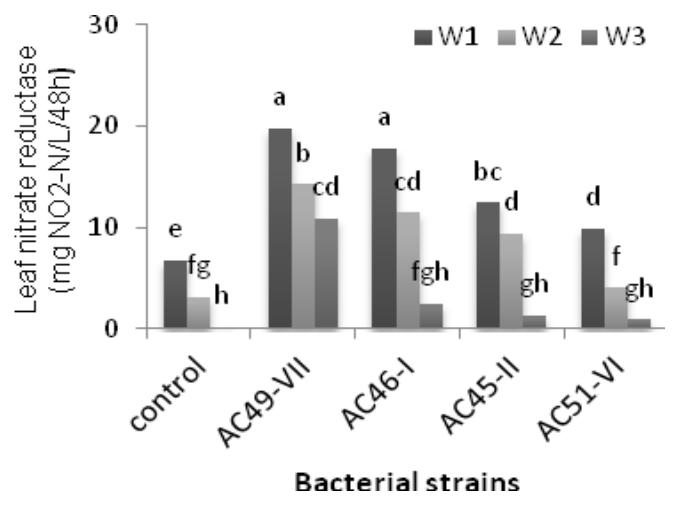

Fig. 6 Effects of soil water deficit levels and bacterial strains on leaf nitrate reductase activity.

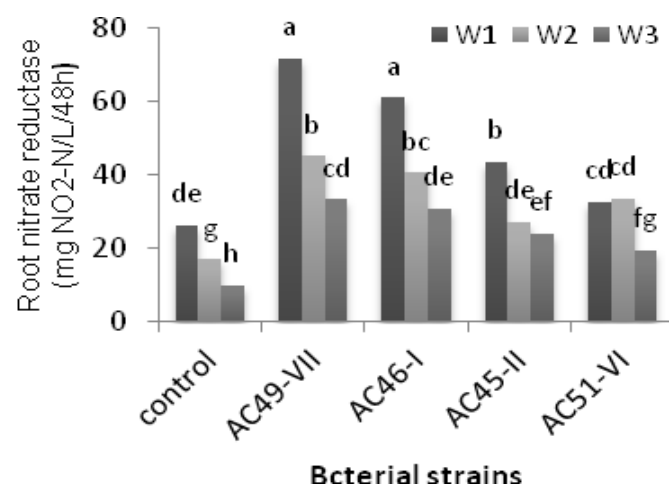

Fig. 7 Effects of soil water deficit levels and bacterial strains on root nitrate reductase activity.

\section{CONCLUSIONS}

A considerable amount of wheat is produced in dry land systems, worldwide. Water deficit and lower nitrogen supply are the most limiting factors affecting wheat yield in these systems. In sustainable agriculture, application of chemical fertilizers is not recommended due to their adverse impacts on ecosystem and also due to economical viewpoints. Application of effective $\mathrm{N}_{2}$ fixers in these systems is an environmentally friendly solution for $\mathrm{N}$ supplying. However, finding of this study and other reports [17], [14] indicate that higher $\mathrm{N}_{2}$ fixation alone could not be sufficient for this purpose but a higher nitrate reductase activity is also essential for incorporation of nitrogen into plant. Among the strains tested in this study, AC49-VII with the highest nitrogenase and NR activities was the superior strain for wheat production, even in higher water deficit conditions. However, field experiments are necessary for its recommendation as a nitrogen biofertilizer for wheat plant.

\section{ACKNOWLEDGMENT}

Authors wish to thank Dr. M. Olamaee and Dr. M. H. Arzanesh from Soil Science Department, Gorgan University of Agricultural Sciences and Natural Resources for providing the bacterial strains. Financial support by the Research Affairs of the University of Tabriz is gratefully acknowledged.

\section{REFERENCES}

[1] D. Seckler, D. Molden, and R. R. Sakthivadivel, "The concept of efficiency in water resource management and policy" Sri Lanka, Colombo: International Water Management Institute, 2003.

[2] N. Druart, P. Goupil, E. Dewaele, J. P. Boutin and S. Rambour, "Nitrate assimilation in chicory roots (Cichorium intibus L.) which acquire radial growth" J. Exp. Bot., vol. 51, pp.539-546, 2000.

[3] Z. Z Xu, and Yu, Z. W. "Nitrogen metabolism in flag leaf and grain of wheat in response to irrigation regimes" J. Plant Nutr. Soil Sci., vol. 169 , pp. $118-126,2006$.

[4] S. C. Ghosh, K. Asanuma, K. Kusutani, and M. Toyota, "Effects of moisture stress at different growth stages on the amount of total nonstructural carbohydrate, nitrate reductase activity and yield of potato" Jpn. J. Trop. Agr., vol. 44, pp. 158-166, 2000.

[5] C. H. Foyer, M.H. Valadier, A. Migge, and T. W. Becker, "Droughtinduced effects on nitrate reductase activity and mRNA and on the coordination of nitrogen and carbon metabolism in maize leaves" Plant Physiol., vol. 117, pp. 283-292, 1998.

[6] Z. Z. Xu, and G. S. Zhou, "Effects of water stress on photosynthesis and nitrogen metabolism in vegetative and reproductive shoots of Leymus chinensis" Photosynthetica, vol. 43, pp. 29-35, 2005.

[7] C. B. Ferreira-Mery, M. S. Fernandes, and J. Döbereiner, "Role of Azospirillum brasilense nitrate reductase in nitrate assimilation by wheat plants" Biol. Fertil. Soils, vol. 4, pp. 47-53, 1987.

[8] N. Smirnoff, M. D. Winslow, and G. R. Stewart, "Nitrate reductase activity in leaves of barley (Hordeum vulgare) and durum wheat (Triticum durum) during field and rapidly applied water deficits". J. Exp. Bot., vol. 36, pp. 1200-1208, 1985.

[9] K. G. Wasnik, P. B. Varade, and A. K. Bagga, "Nitrate reductase activity in chickpea (Cicer arietinum L.) leaves, roots and nodules in relation to moisture stress" Indian J. Plant Physiol., vol. 31, pp. 324327, 1988.

[10] D. L. Shanner, and J. S. Boyer, "Nitrate reductase activity in maize (Zea mays L.) leaves". Plant Physiol., vol. 58, pp. 499-504, 1976.

[11] A. N. Lahiri, "Interaction of water stress and mineral nutrition on growth and yield" in Adaptation of Plants to Water and Higher Temperature Stress, N. C. Turner, and P. J. Kramer, Eds. John Wiley and Sons, New York, pp. 341-352, 1980.

[12] Y. Bashan, and G. Holguin, "Azospirillum-plant relationships: environmental and physiological advances (1990-1996)" Can. J. Microbiol., vol. 43, pp. 103-121, 1997. 
[13] N. Ilyas, and A. Bano, "Azospirillum strains isolated from roots and rhizospher soil of wheat (Triticum aestivum L.) grown under different soil moisture conditions" Biol. Fertil. Soils, vol. 46, pp. 393-406, 2010.

[14] R. M. Boddey, V. L. D. Baldani, J. I. Baldani, and J. Döbereiner, "Effect of inoculation of Azospirillum spp. on nitrogen accumulation by field -gown wheat" Plant Soil, vol. 95, pp. 109-121, $1986 b$.

[15] Y. Kapulnik, S. Sarig, I. Nur, Y. Okon, and Y. Henis, "The effect of Azospirillum inoculation on growth and yield of corn" Isr. J. Bot. vol.31, pp.247-255, 1982.

[16] W. Y Lin, Y. Okon, and R. W. F. Hardy, "Enhanced mineral uptake by Zea mays and Sorghum bicolor roots inoculated with Azospirillum brasilense" Appl. Environ. Microbiol. vol. 45, pp. 1775-1779, 1983.

[17] V. L. D. Baldani, J. I. Baldani, and J. Döbereiner, "Effect of Azospirillum inoculation on root infection and nitrogen incorporation on wheat" Can. J. Microbiol., vol. 29, pp. 924-929, 1983

[18] R. C. Dubey, and K. D. Maheshwari, "Practical Microbiology" S. Chand and Company Ltd. pp. 117, 2005.

[19] N. Ghaderi Golezani, "Evaluation of potential Azospirillum spp. as plant growth promoting rhizobacteria for increasing canola (Brassica napus L.) yield in Gorgan province" M.Sc. Dissertation, Gorgan University of Agricultural Science, 2010.
[20] J. Do öbereiner, "Isolation and identification of aerobic nitrogenfixing bacteria from soil and plants" in Methods in Applied Soil Microbiology and Biochemistry, K. Alef and P. Nannipieri, Eds. Academic Press. London, UK. pp. 134-141, 1995.

[21] E. G. Jaworski, "Nitrate reductase assay in intact plant tissues" Biochem. Biophysic. Res. Commun., vol. 43, pp. 1274-1279, 1971.

[22] M. H. Arzanesh, H. A. Alikhani, K. Khavazi, H. A. Rahimian, and M. Miransari, "Wheat (Triticum aestivum L.) gowth enhancement by Azospirillum sp. under drought stress" World J. Biotechnol., vol. 26, pp.101-109, 2010

[23] H. M. Abdel-samad, H. M. El-komy, M. A. K. Shaddad, and A. M. Hetta, "Effect of molybdenum on nitrogenase and nitrate reductase activities of wheat inoculated with Azospirillum brasilense gown under drought stress" Plant Physiol., vol.31, pp.43-54, 2005.

[24] G. Dannerberg, A. Kronenberg, A, Neuer, and H. Bothe, "Aspects of nitrogen fixation and denitrification by Azospirillum" Plant Soil, vol. 90, pp. 193-202, 1986.

[25] F. R. Warembourg, R. Dressen, K. Vlassak, and F. Lafont, "Peculiar effect of Azospirillum inoculation on growth and nitrogen balance of winter wheat (Triticum aestivum)" Biol. Fertil. Soils, vol. 4, pp. 5559, 1987.

[26] H. M. EL-Komy, M. A. Hamdia, and G. K. Abdel-Baki, "Nitrate reductase in wheat plants gown under water stress and inoculated with Azospirillum spp" Biologia Plantarum, vol. 46, pp. 281-287, 2003 . 